\title{
Influence of Bacillus Spp. Based Bioproducts on Potato Plant Growth and Control of Rhizoctonia Solani
}

\author{
Sorina DINU ${ }^{1}$, Oana-Alina BOIU-SICUIA ${ }^{1,2^{*}}$, Florica CONSTANTINESCU ${ }^{1}$ \\ ${ }^{1}$ Research-Development Institute for Plant Protection, 8 Ion Ionescu de la Brad Blvd., PC 013813, \\ Bucharest, Romania. \\ ${ }^{2}$ University of Agricultural Sciences and Veterinary Medicine - Bucharest, Faculty of Biotechnology, 59 \\ Mărăști Blvd., PC 011464, Bucharest, Romania. \\ "corresponding author: sicuia_oana@yahoo.com
}

Bulletin UASVM Animal Science and Biotechnologies 76(1)/ 2019

Print ISSN 1843-5262; Electronic ISSN 1843-536X

DOI:10.15835/buasvmcn-asb: 2018-0022

\begin{abstract}
Some Bacillus based bioproducts were analyzed for their plant growth promotion and Rhizoctonia solani biocontrol potential in potato plants. The bioproducts were formulated as concentrated aqueous suspension, each containing one of the following plant beneficial bacteria: Bacillus safensis Rd.b2, Bacillus spp. 75.1s and Cp.b4 strains. These were applied on potato seeding material in order to evaluate plant growth promotion effects. The biocontrol efficacy was also evaluated, using Rhizoctonia solani DSM 63002 as plant pathogen, and Prestige 290FS as reference chemical treatment.In the plant growth-promotion experiments, several biologic parameters were biometrically evaluated. Best results regarding plant growth and vigor were obtained using CropMax, a commercial phytostimulatory product. However, the bacterial treatment with Bacillus spp. Cp.b4 and 75.1s showed an improved plant growth compared to the untreated control. An efficacy of $93.75 \%$ against Rhizoctonia dumpingoff was registered when using the Prestige 290FS chemical control. Mix treatments based on this pesticide, in low dose, combined with Cp.b4 or 75.1s biocontrol strains significantly reduced the pathogenic attack, showing 85 to 87.5\% efficacy.The present research demonstrated that the bacterial bioproducts based on Bacillus spp. 75.1s and Cp.b4 strains increase plant growth and are highly effective in controlling Rhizoctonia attack in potato plants.
\end{abstract}

Keywords: Bacillus, biocontrol, bacterial bioproducts, potato.

\section{Introduction}

Plant growth-promoting rhizobacteria (PGPR) are a group of beneficial root associated bacteria, enhancing plant growth, health and soil fertility. Some of them can present an excellent combination of useful traits for plant protection along with growth promotion (Harish et al., 2009). PGPR may influence plant growth by synthesizing plant hormones or improving soil nutrients uptake through different mechanisms, such as atmospheric nitrogen fixation, phosphate and phytate solubilization, phytohormones production and siderophore synthesis, thus making nutrients more available to plants (Glick et al., 2007). Bacillus is one of the most potential genera among the PGPR cluster due to its spore forming ability, which increases their viability during commercial formulation and field application (Liu and Sinclair, 1993). Bacillus is capable of plant growth stimulation (El-Meleigi et al., 2017) and some species suppress plant pathogens and pests by producing antibiotic metabolites. Several Bacillus spp. strains are able to stimulate plant host defenses prior to pathogen infection (van Loon, 2007), thus contributing to increased crop production. Endophytic colonization and biofilm formation of Bacillus and Paenibacillus spp. also improve the biocontrol ability (Davey and O'toole, 2000; Hallmann et al., 1997; Timmusk et al., 2005). Therefore, the use of such microorganisms 
for plant protection and growth promotion could prevent environmental, food and feed risks resulting from chemical pesticides and fertilizers. Nowadays, some biological products based on Bacillus subtilis and B. amyloliquefacins approved phytosanitary products for plant protection (Commission Regulation (EU) 2017/1777).

Among cultivated plants, potato (Solanum tuberosum L.) is mentioned as the third most important food crop after wheat and rice (International Potato Center, 2018). In 2016, Romania was ranked the $16^{\text {th }}$ country worldwide, considering the harvested area, having 186233ha sown with potatoes (FAOSTAT, 2018). Taking into account the reduced potato yield obtained in our country, only 14.4 t/ha on average (FAOSTAT, 2018), we focused on some plant growth promotion products with biocontrol potential. Therefore, we analysed some Bacillus based bioproducts for their plant stimulatory effect and biocontrol efficacy against Rhizoctonia solani on potato plants.

\section{Materials and methods}

Three plant beneficial bacteria Bacillus safensis Rd.b2, Bacillus spp. 75.1s and Cp.b4 strains were formulated as concentrated aqueous suspension. These bacteria are native Romanian strains, previously isolated due to their plant beneficial potential and antifungal activity. Bacterial strains were preserved in the RDIPP microbial collection, at $-80^{\circ} \mathrm{C}$, in $20 \%$ glycerol. Routinely, the bacteria were grown in Luria/Miller agar (1\% tryptone; $0.5 \%$ yeast extract; $1 \% \mathrm{NaCl}, 1.8 \%$ agar, $\mathrm{pH} 7.2$ ). Bacterial biomass was obtained in Luria/Miller broth, after $72 \mathrm{~h}$ of incubation at $28^{\circ} \mathrm{C}$, under rotary shaking at $150 \mathrm{rpm}$, in $100 \mathrm{ml}$ flasks. The bacterial growth was aseptically harvested by centrifugation. Bacterial inoculum was formulated as concentrated aqueous suspension, diluted to $1.2 \times 10^{8} \mathrm{ufc} / \mathrm{ml}$ at application time.

Two types of experiments were performed in order to analyze the influence of beneficial bacteria inoculation on potato plants. One of these experiments was focused on plant growth promotion and the other on biological control of black scurf caused by Rhizoctonia disease in potato.

Potato tuber eyes were used as planting material. These are axillary buds, enclosed by a leaf scar on the potato tuber. The potato tuber eyes were collected with a melon ball scoop $(2 \mathrm{~cm}$ in diameter) in order to provide some adjacent nutritional tuber tissue, similar for each collected "eye". In both experiments, we used Solanum tuberosum L. Arizona cultivar.

In the plant growth-promotion trials, the potato tuber eyes were immersed for 15 minutes in Bacillus based bioproducts supplemented with $2 \%$ carboxy-methyl cellulose to improve bacterial adhesion to the plant tissue. An untreated reference was considered, were the potato tuber eyes were immersed in sterile distilled water. CropMax $^{\circledR}$ ecological fertilizer was used as reference treatment for plant growth stimulation. This commercial fertilizer was used at the recommended dose of $0.1 \%$ for potato culture. The experiment was conducted in plastic pots $(40 / 28 / 10 \mathrm{~cm})$ filled with universal peat mixture. Plants were watered daily, maintained at $25^{\circ} \mathrm{C}$ during daytime and at $20^{\circ} \mathrm{C}$ during night. Several biometric assessments were made, five weeks after planting, regarding root and shoot length $(\mathrm{cm})$, fresh and dry matter weight (g). Seedling vigor index (SVI-II) was calculated based on these results (Shruthi et al., 2018), using the following formula:

SVI-II = Germination percentage $\mathrm{x}$ Mean seedling dry weight $(\mathrm{g})$.

In the plant protection trials, Rhizoctonia solani DSM 63002 strain was used as fungal phytopathogen. The mycelium was grown on sterilized barley seeds, at $25^{\circ} \mathrm{C}$, for two weeks. Fungal inoculum was applied to disinfected soil in $2 \%(\mathrm{w} / \mathrm{w})$ concentration. Artificially infected soil was maintained at room temperature, $24 \mathrm{~h}$ before use, to increase fungal colonization of the substrate.

Mixtures of Bacillus based bioproducts supplemented with $2 \%$ carboxy-methyl cellulose and combined with chemical pesticide in half dose $(0.04 \%)$ were used as experimental treatments. As reference treatment, we used Prestige 290FS chemical pesticide, based on imidacloprid 140 $\mathrm{g} / \mathrm{l}$ and pencycuron $150 \mathrm{~g} / \mathrm{l}$, at the recommended dose of $0.08 \%$ for potato crop.

In the plant protection experiment the planting material was placed in plastic pots filled with $125 \mathrm{~g}$ of artificially infected soil. Two control variants were included in this experiment. One control consisted of untreated tuber eyes planted in artificially infected soil. Another untreated 
Table 1. Plant growth parameters

\begin{tabular}{lcccccc}
\hline \multirow{2}{*}{ Experimental variants } & \multicolumn{2}{c}{ Length $(\mathrm{cm})$} & \multicolumn{2}{c}{ Fresh weight $(\mathrm{g})$} & \multicolumn{2}{c}{ Dry weight $(\mathrm{g})$} \\
\cline { 2 - 6 } & Shoot & Root & Shoot & Root & Shoot & Root \\
\hline Untreated Control & 30.67 & 8.67 & 3.99 & 0.37 & 0.19 & 0.037 \\
\hline CropMax 0.1\% & 36.00 & 9.00 & 5.56 & 0.65 & 0.26 & 0.060 \\
\hline Bacillus safensis Rd.b2 & 36.00 & 9.33 & 3.96 & 0.33 & 0.17 & 0.027 \\
\hline Bacillus sp. 75.1s & 29.00 & 7.67 & 4.24 & 0.42 & 0.21 & 0.030 \\
\hline Bacillus sp. Cp.b4 & 36.00 & 9.00 & 5.10 & 0.43 & 0.23 & 0.040 \\
\hline
\end{tabular}

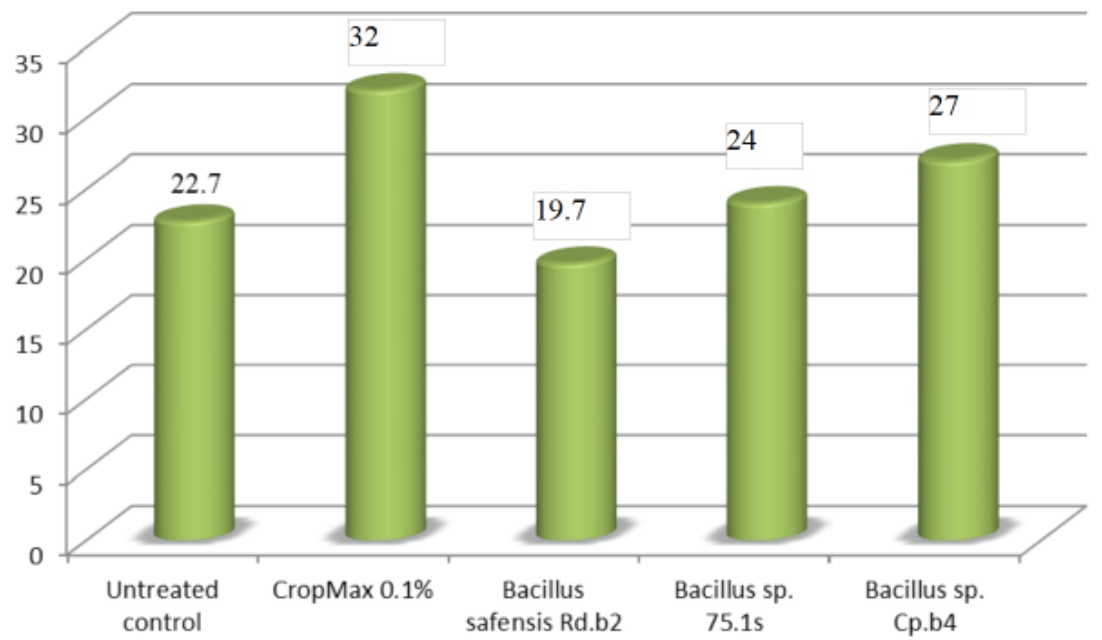

Figure 1. Seedling vigor index (SVI-II)

control, with healthy potato tuber eyes, was grown in disinfected soil, without Rhizoctonia solani inoculum. Each variant was performed in four replicates. All variants were randomly placed in a Sanyo MLR-351H growth chamber. Plant growth conditions were programmed at $65 \%$ relative humidity and 12 hours photoperiods, at $26^{\circ} \mathrm{C}$ during daylight, and $20^{\circ} \mathrm{C}$ during night. This experiment was performed twice with similar results.

The incidence of Rhizoctonia solani fungus and the biocontrol efficacy were estimated according to Almoneafy et al. (2012), five weeks after planting. Disease incidence (DI) was calculated and recorded on a 0 to 4 scale (Park et al., 2007), as follows: $\mathbf{0}=$ no symptoms; $\mathbf{1}=1 \div 25 \%$ disease symptoms; $\mathbf{2}=26 \div 50 \%$ disease symptoms; $\mathbf{3}=$ $51 \div 75 \%$ disease symptoms; $\mathbf{4}=76 \div 100 \%$ disease symptoms or dead plants, where:

$D I \%=\frac{\text { Disease index } \times \text { Number of diseased plants in this index }}{\text { Total number of investigated plants } \times \text { Highest disease index }} \times 100$

The biocontrol efficacy (E\%) was calculated based on the disease incidence in the control and treatment variants (Xue et al., 2009), using the following formula:

$$
E \%=\frac{D I_{C}-D I_{T}}{D I_{C}} \times 100
$$

where: $E E \%$ = percentage of biocontrol efficacy; $\mathrm{DI}_{\mathrm{C}}=$ disease incidence in control; $\mathrm{d}=$ disease incidence in the treatment variant.

\section{Results and discussions}

Five weeks old potato plants were analyzed after being treated with different biologic products. Several growth parameters were biometrically assessed, such as shoot and root length, fresh and dry weight (Tab. 1).

Best results were registered when CropMax commercial biofertilizer was used. Due to its complex formula which includes 17 amino acids, six microelements, polysaccharides, vitamins, enzymes and carotenoids. This treatment led to the highest fresh and dry weight of potato plants. Farmers that used CropMax fertilizer in Solanaceous crops mentioned an increased production of 22 to $26 \%$ (www.verdon.ro).

Among bacterial treatments, results were better when Bacillus sp. Cp.b4 strain was used. However, plant roots had a lower fresh and dry 


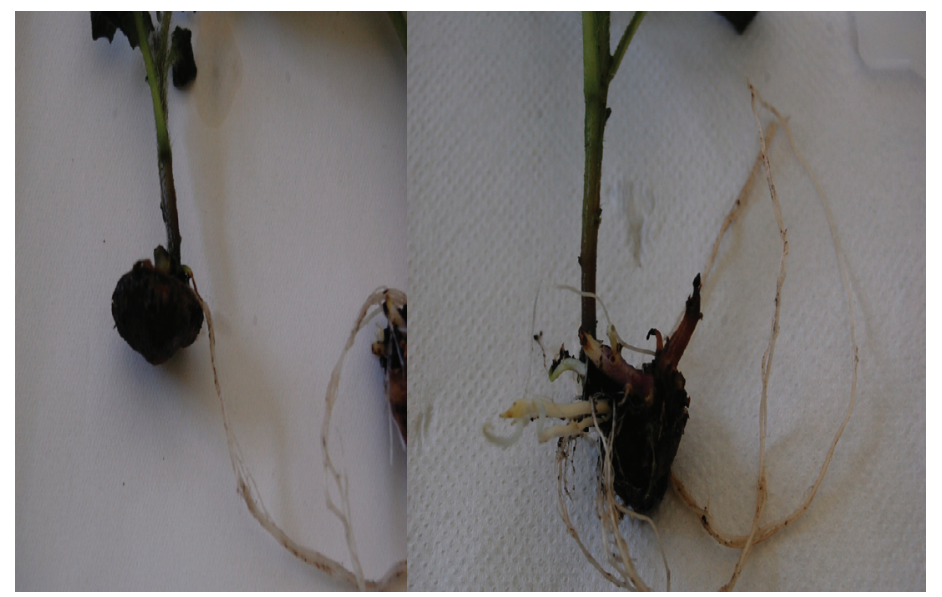

Figure 2. Rhizoctonia solani disease symptoms in potato plants

weight, compared to plants treated with the commercial growth improver.

Compared to the untreated control, no significant differences were noticed when Bacillus sp. 75.1s bioproduct was applied.

The potato treatment with Bacillus safensis Rd.b2 strain, although induced higher shoot and longer roots, did not increase plant vigor. Due to the low fresh and dry weight of the plants it can be concluded that this treatment predisposed the plant to elongation. Therefore, such treatment should not be recommended for potato plants.

The seedling vigor index was calculated considering the plants' dry weight. Best results were obtained with the CropMax treatment (Figure 1). Bacterial treatment with Cp.b4 strain also increased the seedling vigor index compared to the untreated control. However, the other two bacterial treatments were not significantly different compared to the untreated control.

A desirable characteristic for PGPR is the capacity to produce phytohormones, like auxins. Several species of Bacillus have been reported to produce auxins (Calvo et al., 2010; Kesaulya et al., 2017). Idris et al., (2007) have shown that mutants of B. amyloliquefaciens FZB42 with diminished levels of IAA production were less efficient in promoting plant growth. Plant growth promotion is also improved by phosphate solubilizing bacteria (Zaidi et al., 2009). Several other mechanisms were developed by Bacillus rhizobacteria to enhance plant growth. For plant associated microorganisms an important aspect is to increase nutrients availability. Among the Bacillus species, B. megaterium, B.subtilis, B. pumilus, B. polymyxa, $B$. sphaericus, $B$. thuringiensis were reported to solubilize phosphorus form insoluble inorganic phosphate or by mineralization of organic phosphorous (De Freitas et al., 1997, Saeid et al., 2018).

Other plant beneficial characteristics in rhizobacteria are related to their biocontrol potential. Rhizoctonia solani is a plant disease that attacks underground sprouts of potato plants before they emerge from the soil. At first, the fungal lesion induces superficial brown areas that have no apparent effect on plant growth. If the disease is not suppressed, the translocation of starch from leaves to the tubers is affected. The lesions expand and canker is installed. Large and sunken tissue areas become necrotic (figure 2) and the disease expands quickly. The yield is significantly reduced in such cases. Rhizoctonia solani could also be responsible for black scurf.

In the plant protection experiments against Rhizoctonia dumping-off, the chemical treatment with $0.08 \%$ Prestige $290 \mathrm{FS}$ revealed an efficacy of $93.75 \%$. Reducing the chemical dose to half and supplementing this treatment with Bacillus spp. biocontrol bacteria we obtained an efficacy of 85\% (with Cp.b4) to 87.5\% (with 75.1s) in controlling Rhizoctonia disease (Tab 2).

Among the complex treatments, the combination of Bacillus sp. 75.1s suspension with the low pesticide dose was more efficient than the complex treatment containing the Bacillus sp. Cp.b4 strain.

Other studies performed with Prestige 290FS against Rhizoctonia plant pathogen mention a good efficacy both in vitro and in vivo trials. At high concentrations of this pesticide $(1 \div 10 \mathrm{mg} / \mathrm{L})$, the Rhizoctonia mycelium stops growing, and at 0.1 
Table 2. Rhizoctonia disease control in potato

\begin{tabular}{lcc}
\hline Experimental variants & E (\%) & DI (\%) \\
\hline Negative control - Without artificial infection & - & 0 \\
\hline Positive control - Artificial infection with Rhizoctonia solani DSM 63002 & 0 & 100 \\
\hline $\begin{array}{l}\text { Chemical control - 0.08\% Prestige 290FS (140 g/l imidacloprid and 150 g/l } \\
\text { pencycuron) }\end{array}$ & 93.75 & 6.25 \\
\hline Complex treatment with Bacillus sp. Cpb4 and 0.04\% Prestige 290FS & 85 & 15 \\
\hline Complex treatment with Bacillus sp. 75.1s and 0.04\% Prestige 290FS & 87.5 & 12.5 \\
\hline
\end{tabular}

$\mathrm{mg} / \mathrm{L}$ the mycelium reached only $2.3 \%$ the size of the control (Šafránková, 2004). However, another study mention that Prestige 290FS presented the weakest protective effect against Rhizoctonia solani on potato plants (Cwalinska-Ambroziak and Trojak, 2012), when analyzed compared to other pesticides (Dithane M 4575 WG, Vitavax 2000 FS) and biocontrol agents (Polyversum). This suggests that a lower dose of Prestige 290FS should be supplemented with other chemical or biological means to control Rhizoctonia solani more effectively in potato plants.

\section{Conclusions}

Bacterial bioproducts based on Bacillus sp. 75.1s and Cp.b4 strains increase plant growth and have high efficacy in controlling Rhizoctonia attacks in potato plants. Between the two bacterial strains, better results were obtained for growth promotion with Cp.b4 strain compared to $75.1 \mathrm{~s}$ strain. However, in the plant protection experiment, the complex treatment containing Bacillus sp. 75.1s revealed a higher efficacy against Rhizoctonia dumping-off. Best results were obtained in both experiments with the commercial products, CropMax as phytostimulatory product, and Prestige 290FS as plant protection product.

Acknowledgments. This work was supported by a grant of the Romanian Ministry of Research and Innovation, CCCDI-UEFISCDI, project number PNIII-P1-1.2-PCCDI-2017-0301, within PCCDI III.

\section{References}

1. Almoneafy AA, Xie GL, Tian WX, Xu LH, Zhang GQ, Ibrahim $M$ (2012). Characterization and evaluation of Bacillus isolates for their potential plant growth and biocontrol activities against tomato bacterial wilt. African Journal of Biotechnology, 11(28): 7193-7201.

2. Calvo P, Ormeño-Orrillo E, Martínez-Romero E, Zúñiga D (2010). Characterization of Bacillus isolates of potato rhizosphere from andean soils of Peru and their potential PGPR characteristics. Brazilian Journal of Microbiology, 41(4): 899-906.

3. Commission Regulation (EU) 2017/1777 of 29 September 2017 amending Annexes II, III and IV to Regulation (EC) No 396/2005 of the European Parliament.

4. Cwalinska-Ambroziak B, Trojak A (2012). The effect of seed potato dressing on the severity of rhizoctoniose and anthracnose. Progress in Plant Protection, 52(3): 614618. D0I: bwmeta1.element.agro-ec0902e1-0908-4ab2b9d3-e90519fd6366

5. Davey ME, O’Toole GA (2000). Microbial Biofilms: From Ecology to Molecular Genetics. Microbiol. Mol. Biol. Rev., 64(4): 847-867.

6. De Freitas JR, Banerjee MR, Germida JJ (1997). Phosphatesolubilizing rhizobacteria enhance the growth and yield but not phosphorus uptake of canola (Brassica napus L.). Biol Fertil Soils, 24: 358-364.

7. El-Meleigi M.A., Omar A.F., Rogaibah A.A., Ibrahim G.H. (2017). Efficacy of Bacilli strains in growth promotion and biological control of soilborne Rhizoctonia and Fusarium on Alfalfa (Medicago sativa L.) and Potato (Solanum tuberosum L). Egyptian Journal of Biological Pest Control. 27 (1): 85-92.

8. FAOSTAT (2018). http://www.fao.org/faostat/en

9. Glick BR, Todorovic B, Czarny J, Cheng Z, Duan J, Mc Conkey B (2007). Promotion of Plant Growth by Bacterial Acc Deaminase. Crit. Rev. Plant Sci., 26(5-6): 227-242.

10. Hallmann J, Quadt-Hallmann A, Mahaffee WF, Kloepper JW (1997). Bacterial Endophytes in Agricultural Crops Can J Microbiol, 43: 895-914.

11. Harish S, Kavino M, Kumar N, Balasubramanian P, Samiyappan R (2009). Induction of Defense-Related Proteins by Mixtures of Plant Growth Promoting Endophytic Bacteria against Banana Bunchy Top Virus. Biol Control, 51(1): 16-25.

12. https://www.verdon.ro/ingrasaminte-foliare-si-prinpicurare/ingrasamant-bio-cropmax-100-natural-1-l.html

13. Idris EE, Iglesias DJ, Talon M, Borriss R (2007). Tryptophandependent production of indole-3-Acetic Acid (IAA) affects level of plant growth promotion by Bacillus amyloliquefaciens FZB42. Mol. Plant-Microbe Interact, 20 (6), 619-626.

14. International Potato Center (2018). https://cipotato.org/ crops/potato/ 
15. Kesaulya H, Hasinu JV, Tuhumury GNC, (2017). Potency of Bacillus spp from potato rhizosphere as active ingredients for biostimulant formulation. Modern Applied Science, 11(10):74. DOI: 10.5539/mas.v11n10p74.

16. Liu ZL, Sinclair JB (1993). Colonization of Soybean Roots by Bacillus megaterium B 153-2-2. Soil Biol. Biochem., 25(7): 849-855.

17. Park EJ, Lee SD, Chung EJ, Lee MH, Um HY, Murugaiyan S, Moon BJ, Lee SW (2007). MicroTom - a model plant system to study bacterial wilt by Ralstonia solanacearum. The Plant Pathology Journal, 23(4): 239-244.

18. Saeid A, Prochownik E, Dobrowolska-Iwanek J (2018) Phosphorus solubilization by Bacillus species. Molecules, 23:2897. DOI: $10.3390 /$ molecules23112897.

19. Šafránková I (2004). Rhizoctoniasolani Kühn anastomosis Group 3 as pathogen of potato and its sensitivity to seedfungicides. Acta Universitatis Agriculturae et Silviculturae Mendelianae Brunensis, LII(1): 67-74.

20. Shruthi K, Balakrishna P, Sreeramu BS (2018). The effects of seed treatments on germination and other seed quality attributes of rosella (Hibiscus sabdariffa Var. sabdariffa
L.). International Journal of Science, Environment and Technology, Vol. 7, No 1, 2018, $201-206$

21. Timmusk S, Grantcharova N, Wagner EGH (2005). Paenibacillus Polymyxa Invades Plant Roots and Forms Biofilms. Appl Environ Microbiol, 71(11): 7292-7300.

22. Van Loon LC (2007). Plant Responses to Plant GrowthPromoting Rhizobacteria. Eur. J. Plant Pathol. 119(3): 243-254.

23. Xue QY, Chen Y, Li SM, Chen LF, Ding GC, Guo DW, Guo $\mathrm{JH}$ (2009). Evaluation of the strains of Acinetobacter and Enterobacter as potential biocontrol agents against Ralstonia wilt of tomato. Biological Control, 48(3): 252258.

24. Zaidi A, Khan MS, Ahemad M, Oves M (2009). Plant growth promotion by phosphate solubilizing bacteria. Acta microbiologica et immunologica Hungarica. 56:263-84. 10.1556/AMicr.56.2009.3.6. 